\title{
南方振動と福岡市月降水量の 相関関係について
}

\author{
河村 明 1 - 江口 聡一郎 $2 \cdot$ 神野 健二3 \\ 1正会員 工博 九州大学助教授 工学研究院（干812-8581 福岡市東区箱崎六丁目10-1) \\ 2学生員 九州大学大学院工学府 (下812-8581 福岡市東区箱崎六丁目10-1) \\ 3 正会員 工博 九州大学教授 工学研究院（广812-8581 福岡市東区箱崎六丁目10-1）
}

\begin{abstract}
これまで, エルニーニョ・ラニーニャ現象の指標となる南方振動指数（SOI）と日本のような中緯度に おける水文気象要素との相関関係は明瞭とはなっていない. 本論文では, 渴水リスクの高い福岡市にお ける110年間の月降水量デー夕を正規変換の後規準化し，それに対応するSOIとの相関関係を解析してい る. その結果, 全時系列を対象とした場合の相関はほとんどゼロであるが, SOIデー夕をその大きさによ りカテゴリーに分類し，そのカテゴリー別に相関関数を解析すると，強いエルニーニヨ・強いラニーニ ヤのカテゴリーにおいて，ある特定の遅れ時間に対し，有意性の高い相関を検出できることが分かった. そして,これらの現象に関連した福岡市月降水量の傾向が見出された。
\end{abstract}

Key Words : Southern Oscillation Index, precipitation, Fukuoka, correlation, El Niño

\section{1.はじめに}

ペルー沖から日付変更線付近にかけての東部太 平洋赤道域において, 海面水温が平年よりも最大 で数度ほど上昇する現象をエルニーニョ現象, 反 対に平年よりも下がる現象をラニーニャ現象と一 般に呼んでいる ${ }^{1), 2)}$. エルニーニョ・ラニーニャ現 象に対応して，その洋上にみられる東西の気圧振 動は南方振動（Southern Oscillation）と呼ばれ, 南 方振動の状態は南方振動指数（Southern Oscillation Index, 以下 SOI と記す) により数值化される ${ }^{3)}$. アメリカ合衆国の国立海洋大気庁（NOAA）では, この SOI によりエルニーニョ・ラニーニャ現象の 判断を行っている2).

エルニーニョ・ラニーニャ現象はテレコネクシ ヨンを通じて世界各地の気象に影響を及ぼし，こ れらの現象に起因すると考えられる異常気象が世 界各地で数多く報告されている ${ }^{1), 2)}$. このような異 常気象の発生や気候変動は, 例えば水資源確保と いう点から見て不安定な要因として懸念されてお り,これに伴い南方振動の定性・定量的解析や予 測, そして南方振動の降水・気温などへの影響評 価が重要な課題となっている.

SOI と世界各国の水文気象要素との関係について は精力的に研究が行われている（例えば，文献 4) ～7）参照）. その結果, 低緯度帯での水文気象要 素と SOI との間には顕著な相関関係が見出されて いる. 一例として, 吉野》はフィリピンとマレーシ
アでの平均月雨量と SOI の変動が非常に良く対応 することを示している.

これまで，エルニーニョが発生した年（エルニ 一ニヨ年）と日本の天候の特徵については，夏に 低温傾向, 冬に暖冬傾向になる場合が多いことが 指摘されている ${ }^{22,8)}$ が，日本のような中緯度におけ る気候へのエルニーニョ・ラニーニャ現象の明瞭 な影響はあまり報告されていない ${ }^{1), 2)}$.そして, 日 本の降水に影響を及ぼす台風発生数などとエルニ 一二ヨ年との関係 ${ }^{2), 9}$ や ，日本の桜の開花日（3 月 の月平均気温などに関係する) とエルニーニョ年 やラニーニャ年との関係 2),10)といったようなエルニ 一ニョ年（ラニーニャ年）に対応させた研究は多 くある.しかし，SOI（月単位で計算される）と日 本における月降水量などの水文気象要素とを直接 用いて関係づける研究は，ほとんど見受けられな い. その数少ない研究として, 吉野 》 と四国の月降水量時系列の関係を解析した結果, 四国の月降水量の変動と SOI との間に, 明瞭な影 響を指摘することは困難であり，これは日本のよ うな中緯度までエルニーニョの直接的な影響は及 ばないことを示していると結論づけている．この ように SOI と日本の水文気象要素を直接用いて相 関解析を行っても明瞭な相関関係は得られないた め, そのような研究結果は余り発表されていない ものと推測される.

本論文では, 月単位でSOIと福岡市月降水量の相 関関係を詳しく解析している. 福岡市は地勢的に 


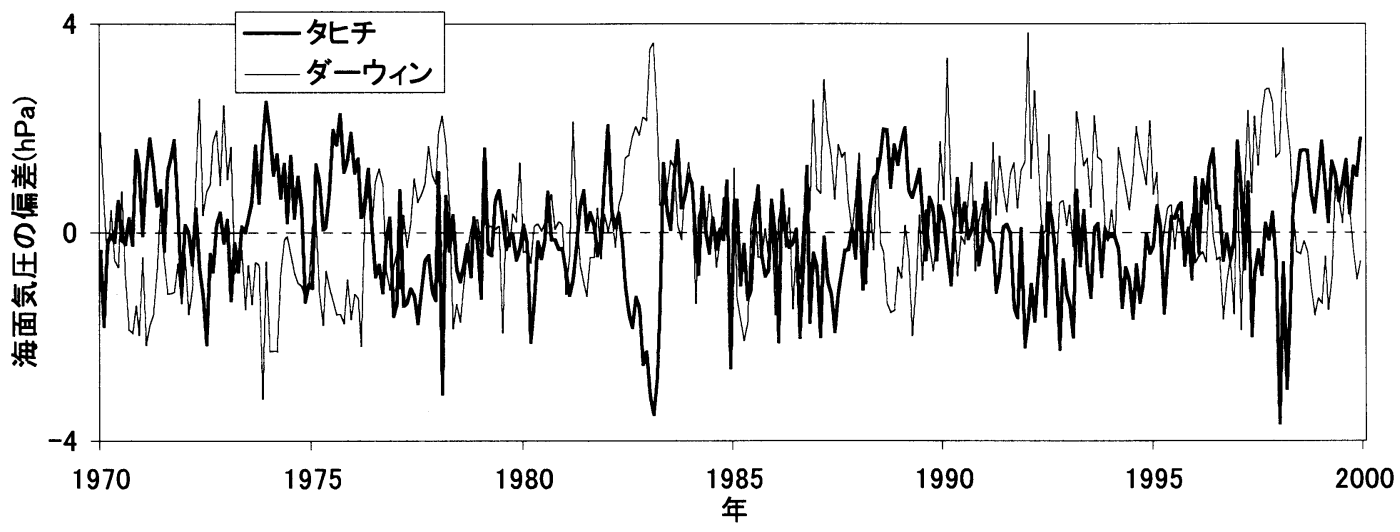

図-1 タヒチおよびダーウィンにおける月平均海面気圧の月平均值からの偏差時系列(1970年1月から 1999年 12月)

水資源に恵まれておらず，常に渴水の危険性にさ らされている．過去において11回もの給水制限を 実施しており，特に，昭和53年や平成6年の大渴水 時には甚大な被害を被っている（詳しくは文献 11），12）を参照）。このため，本地域における水 文気象特性を把握することは，水資源問題上非常 に重要な課題となっている.

本論文でも，SOI時系列と福岡市月降水量時系列 の相関関数を直接計算しているが, 結果は降水量 の遅れ時間に関わらず相関はほとんどゼロとなっ た.しかし，SOIデータをその大きさによりカテゴ リーに分類し，そのカテゴリー別に相関関数を解 析した結果, 難しい数学的手法を用いなくとも, 強いエルニーニョ・強いラニーニャと分類したカ テゴリーにおいて，ある特定の遅れ時間に対し， 有意性の高い相関を検出できることが分かったの でここに報告するものである。これにより，エル ニーニョ・ラニーニャ現象に関連した福岡市月降 水量の有用な傾向が見出された.

\section{2. 用いたSOIおよび福岡市月降水量データ}

(1) SOIデータ

SOI は，南太平洋の夕ヒチ島パペーテ（西経 149.6 度, 南緯 17.5 度) とオーストラリア北部のダ 一ウィン（東経 130.9 度, 南緯 12.4 度）両地点の気 圧データより算定される。これらの月平均海面気 圧デー夕に関しては 1866 年 1 月からの連続デー夕 が得られている（詳しくは文献 13）参照）。

図-1 は，これら両地点における月平均海面気圧 の月平均值からの偏差時系列を, 最近 30 年間分 (1970 年 1 月から 1999 年 12 月)について示したも のである.この図より,一方の地点の気圧が平均 より高くなると, 他方の地点では平均より低くな る傾向がはっきりと認められる。この現象は 20 世 紀はじめWalker 卿により発見され，南方振動 (Southern Oscillation) と名付けられた有名な現象

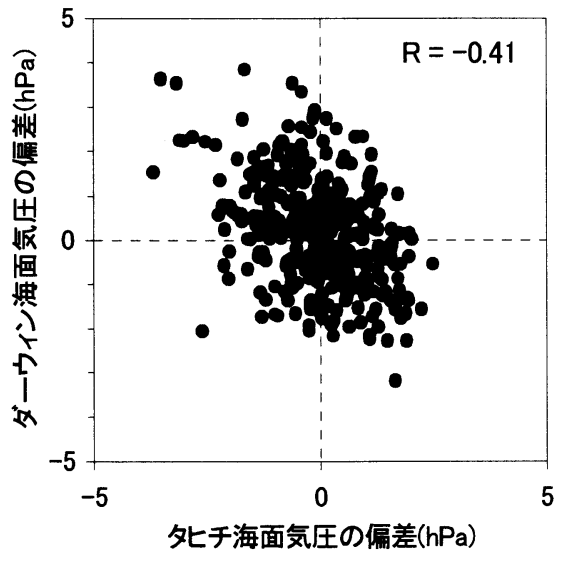

図-2 夕ヒチおよびダーウィンにおける海面気圧の偏差 散布図(1970 年 1 月から 1999 年 12 月)

である ${ }^{2)}$. 南方振動は, この太平洋上における東西 の気圧（他の気象要素は考えない）の振動を指し ておりシーソーにたとえられる.そしてこの南方 振動はエルニーニョ・ラニーニャ現象と相互に関 連している。

図-2に，図-1の 30 年間の海面気圧の偏差散布図 を示しているが，30 年間の南方振動の相関係数は -0.41 となっている. また, 1866 年 1 月からのデ 一夕（134 年間）を用いた場合の南方振動の相関係 数は-0.26 となっていて ${ }^{13)}$, 南方振動の相関係数 そのものは決して大きくはないことが分かる.し かし，これらの相関を相関係数がゼロという帰無 仮説をたて, 統計的仮説検定を実行すると, $0.001 \%$ 以下という非常に高い有意水準でその帰無 仮説は棄てられる ${ }^{13)}$. すなわち, 南方振動の相関 係数は極めて高い有意性を保持しているといえる. このようにデータ数が多い場合（図-2 の場合 360 個，134 年間の場合 1608 個）は, 相関はそれ程高 くなくても，例えば図-2 の場合の相関係数 -0.41 の $95 \%$ 信頼区間は $-0.320 \sim-0.493$ (およそ -0.41 $\pm 0.09 ）$ となり，この相関係数の 95\%信頼区間の幅 


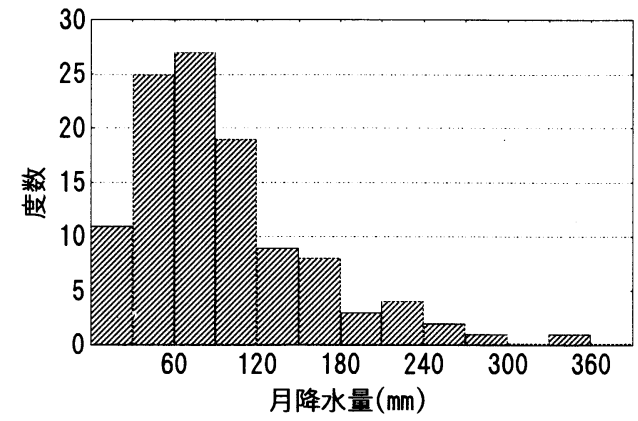

図-3 福岡市 10 月の月降水量ヒストグラム

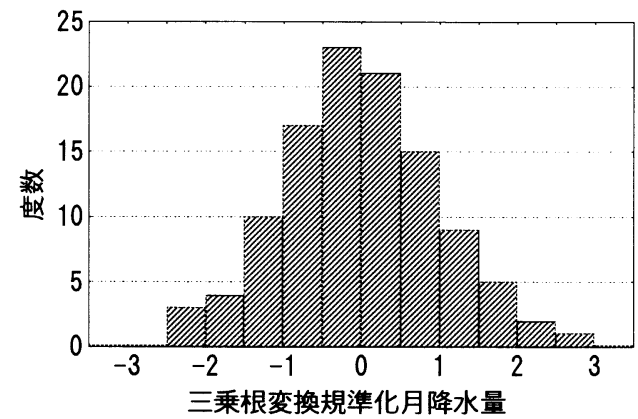

図-4 福岡市 10 月の三乗根変換規準化月降水量ヒス トグラム
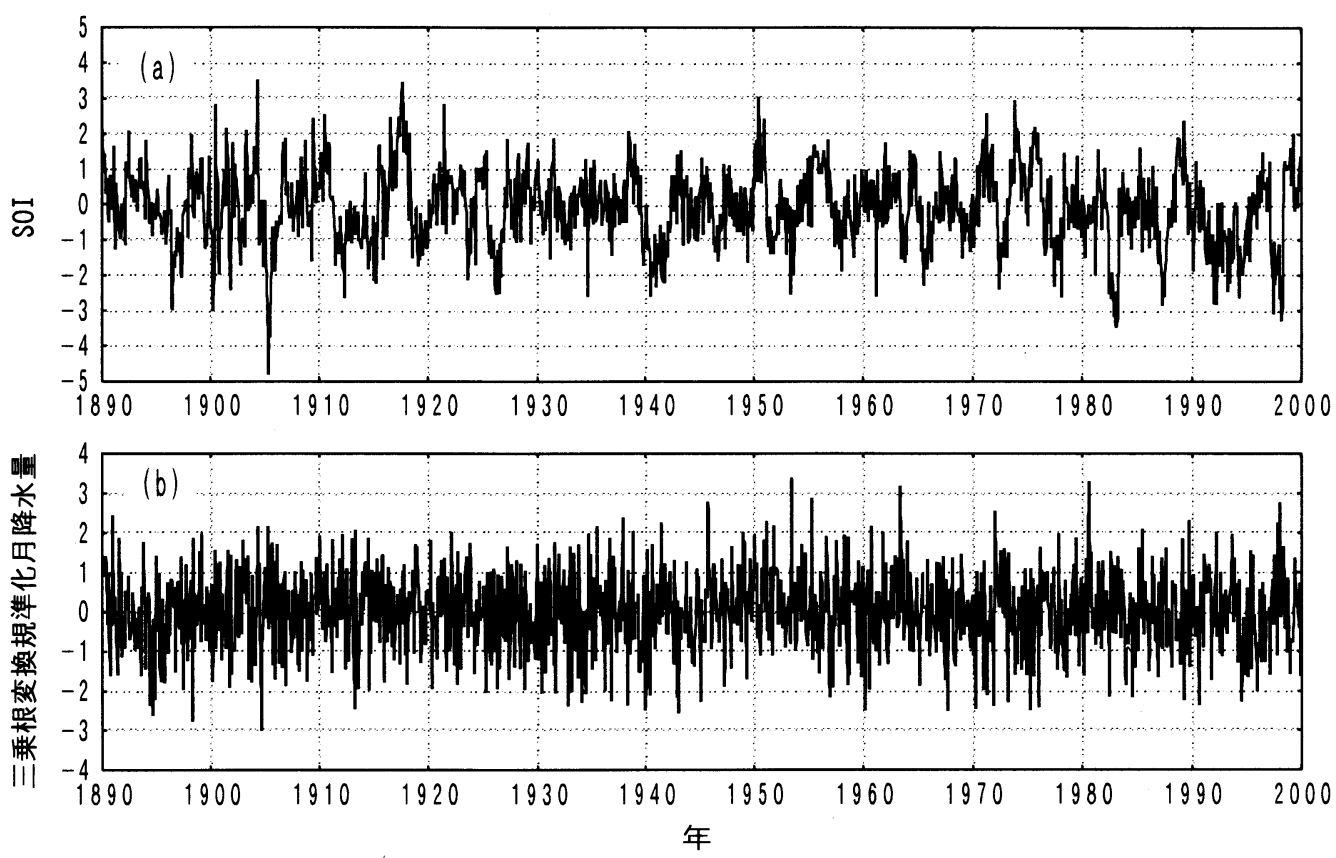

図-5 用いた SOI 時系列(a)および福岡市の三乗根変換規準化月降水量時系列(b)

は非常に小さく，有意性は極めて高いものとなる. 逆に，データ数が少ない場合は，たとえ相関係数 は大きくても偶然そのようになる確率が高くなる ので，その相関係数が有意とはならない場合も生 じてくる．以上のように相関係数の有意性は，相 関係数の大小に関わらず，帰無仮説をベースに検 定される.ただし，両者の相関の強さは，求めら れた相関係数の值で規定される.

さて, タヒチとダーウィンの月平均海面気圧デ 一夕より SOI を算定する方法としては，Troup の方 法と気候予測センターによる方法の 2 つが代表的 である.どちらの SOI も值そのものに大差はない ${ }^{3)}$. ここでは Troup の方法 ${ }^{14), 15) を}$ 用いて SOI を算定する が，この方法による，ある年 $y ，$ ある月 $m(m=1$ 月 〜12 月)における $\operatorname{SOI}(y, m)$ の值は次式で算定される.

$S O I(y, m)=\left[\left\{P_{T}(y, m)-P_{D}(y, m)\right\}-M_{30}(m)\right] / S_{30}(m)$
ここに, $P_{T}(y, m), P_{D}(y, m):$ それぞれタヒチ及びダー ウィンにおける月平均海面気圧 $(\mathrm{hPa}) . M_{30}(m)$, $S_{30}(m)$ : それぞれ基準期間 30 年間（1951 年から 1980 年）における, ある月 $m$ に対する夕ヒチ及び ダーウィンの月平均海面気圧差の平均值 $(\mathrm{hPa})$ およ び標準偏差( $(\mathrm{hPa})$ である ${ }^{13)}$ ．すなわち本方法による SOI は, 夕ヒチとダーウィンの月平均海面気圧の差 を平均 0 , 標準偏差 1 に規準化したものとして表さ れる. そして, SOI がー1 以下の場合エルニーニョ, 1 以上でラニーニャと大まかに判断される. 特に絶 対值が 2 を超えると強いエルニーニョ, ラニーニ ヤと判断される.

なお, SOI時系列の統計的特性（発生頻度特性， 持続特性など）およびカオス特性（自己相関特性, スペクトル特性を含む) については，それぞれ著 者らの文献13),3)を参照されたい。 


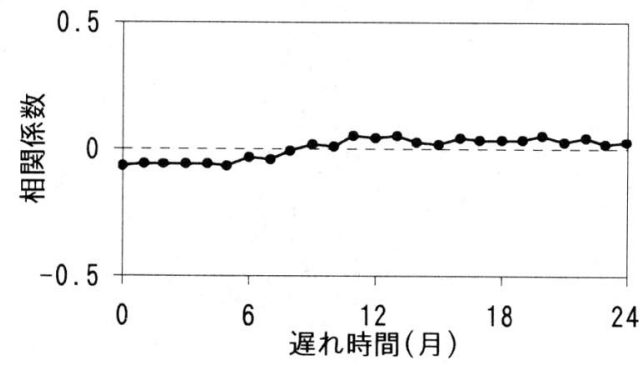

図-6 SOI 時系列之三乗根変換規準化月降水量時系列の 相互相関関数

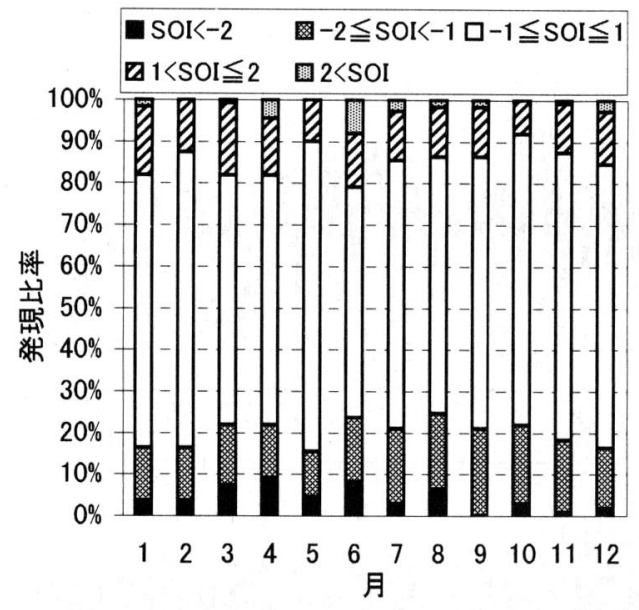

図-7 SOI発現比率

（2）福岡市月降水量データ

福岡市月降水量のデータは 1890 年1月から存在す る. 各月（1～12月)の降水量ヒストグラムは，例え ば図-3（10月のヒストグラム）のように正規分布 ではなく正に歪んでいる ${ }^{16}$ 。一般に月降水量の分布 は非対称であり, 対数変換や $n$ 乗根変換によって正 規分布に近似できるといわれている17).このため， ここでは月降水量に三乗根変換を施して正規変換 し, さらに各月毎に平均値を差し引き, 標準偏差 で割ることによりデータを規準化した。その結果， 例えば図-3のヒストグラムは，図-4のようにおお よそ平均 0 , 標準偏差 1 の正規分布として規準化さ れる. 本論文の以下の解析では, 福岡市月降水量 のデータ数に合わせて，1890年1月から 1999年12月 までの110年間1320ケ月のSOIデータと正規変換後 規準化した福岡市月降水量デー夕を用いて解析を 行っている.これらの時系列を図-5に示す.

\section{SOI と福岡市月降水量との相関}

以上で述べた SOI 時系列と福岡市における三乗 根変換規準化月降水量時系列に対して, 相互相関
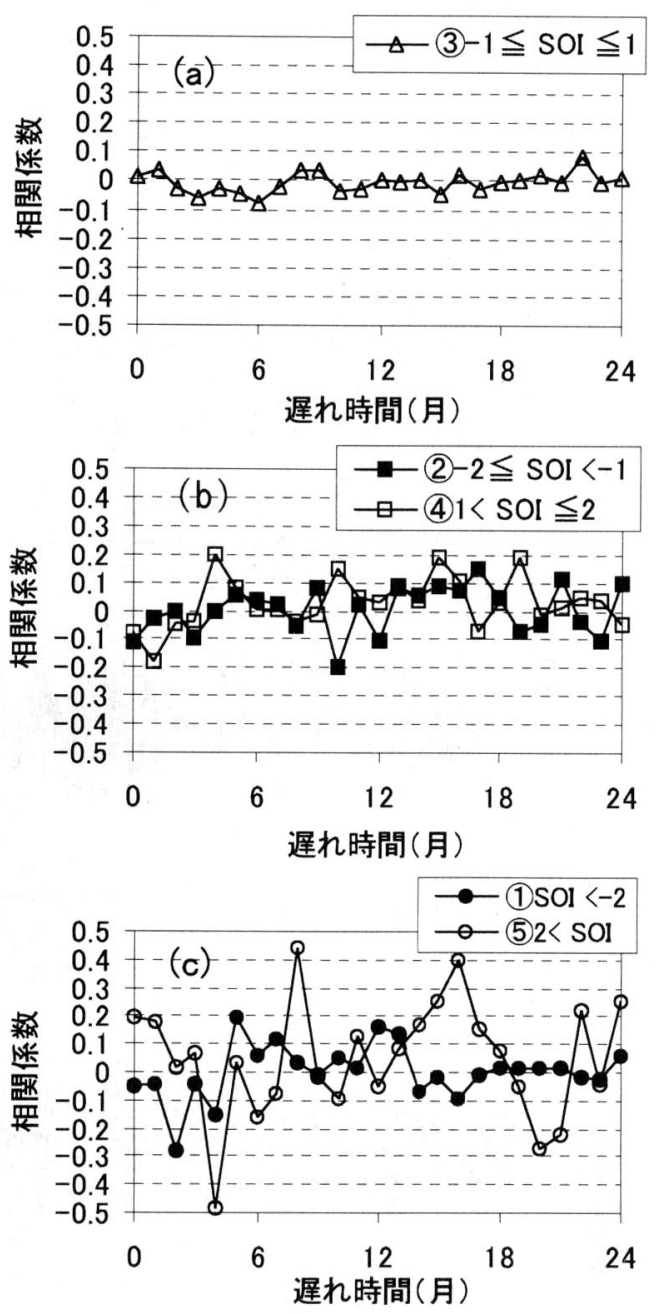

図-8 カテゴリー分類した SOI と対応する三乗根変換規準化月 降水量との相互相関関数

関数(SOI を基準として月降水量を遅れ時間にとる) を算定した．その結果を図-6に示す．この場合， SOI の異常（エルニーニョ・ラニーニャ現象）が原 因となって，世界各地（特に低緯度帯）の水文気 象要素に影響を及ぼすことが気象物理学に説明さ

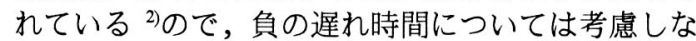
い. 図-6 より，どの遅れ時間に対しても相関係数 はほとんどゼロであり，両者の間に相関関係は見 出せない。この結果は，1.で述べたように，吉 野が四国の月降水量に対して得た結果と同様であ る》。

そこで, SOI のデータをその大きさによって, (1) $\mathrm{SOI}<-2$, (2) $-2 \leqq \mathrm{SOI}<-1$, (3) $-1 \leqq \mathrm{SOI} \leqq 1$, (4) 1 $<\mathrm{SOI} \leqq 2$, (5) $2<$ SOI の 5 つのカテゴリーに分類し, そのカテゴリー毎に三乗根変換規準化月降水量と の相関関数を算定することを試みた。以後，これ らの現象を容易に関連づけるため, カテゴリー1 〜(5)をそれぞれ, 強いエルニーニョ, 弱いエルニ 
一ニヨ, 通常状態, 弱いラニーニャ, 強いラニー ニャと呼ぶことにする. 図-7に，用いた 110 年間 の SOI データについて, 上記の 5 つのカテゴリー の月別発生頻度を示す.この図より, エルニーニ ヨ，ラニーニャはどの月でも発生し，月毎のそれ ぞれのカテゴリーの発現比率にそれ程大きな変動 は見られない（詳しくは文献 13）参照）。この場 合，110 年 1320 ケ月全体のカテゴリー(1)～(5)の発 生比率は，それぞれ，4.2\%，15.6\%，65.5\%，12.6\%， $2.1 \%$ となっている.

さて，上記の 5 つのカテゴリー毎のデータに対 し，ある月の SOI と，その SOI から遅れ時間 $n$ ケ 月後 $(n=0 \sim 24)$ の三乗根変換規準化月降水量との 相関関係について調べた結果を図-8に示す. 図-8 (a)より，エルニーニョおよびラニーニャ現象が生 じていない通常状態（カテゴリー(3)）の場合には， 図-6 同様ほとんど相関が見られないが, SOI の絶 対值が大きくなるにつれて, 図-8(b),(c)のように 相関係数の絶対值も大きくなるという傾向が見て 取れる.この場合, 強いラニーニャ現象の方が強 いエルニーニヨ現象よりも相関が高くなる傾向に ある. 最も相関係数が大きいのは, 強いラニーニ ヤ（カテゴリー(5)）で遅れ時間 $n=4$ ケ月の場合で, 相関係数は -0.48 である.この相関係数は有意水 準 $1 \%$ で有意である.この強いラニーニャのカテゴ リーではその他に, 遅れ時間 $n=8$ ケ月および $n=16$ ケ月の相関係数が有意水準 $5 \%$ で有意である. また， 強いエルニーニョ（カテゴリー(1)）については, 唯一 $n=2$ ッ月の場合に有意水準 5\%で有意な相関が 得られた.

次に，有意な相関が得られた以上の 4 ケースに ついて，その散布図を調べてみよう.まず図-9に， 強いラニーニャ時で遅れ時間 $n=4$ ケ月の場合の散布 図を示す．この図より，SOIが大きくなる(ラニー ニャ現象が顕著になる)程, 4ケ月後の福岡市月降 水量は平年に比べ減少する傾向にあることが認め られる. 次いで, 同じ強いラニーニャで遅れ時間 $n=8,16$ ケ月の散布図をそれぞれ図-10,11に示す.こ れらの図より， $n=4$ ケ月の場合とは逆に, SOIが大 きくなる程福岡市月降水量が増加する傾向が見ら れる. 最後に, 強いエルニーニョ（カテゴリー (1)）で遅れ時間 $n=2$ ケ月の散布図を図-12に示す. この図より, SOIが小さくなる(エルニーニョ現象 が顕著になる)程, 2ケ月後の福岡市月降水量は平 年に比べ（増加するというよりもむしろ）少雨が 出現しにくい傾向にあることが分かる.

ここで得られた SOI と福岡降水量の有意な相関 関係の気象物理的説明については，エルニーニ ヨ・ラニーニャ現象により,太平洋上の熱帯低気 圧の発生位置が東西に移動し，それに伴う周囲の 高気圧・低気圧分布（特に太平洋高気圧）がシフ

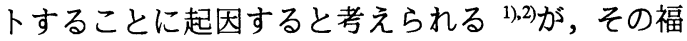
岡市降水への時間的遅れの影響など詳しいことは， 現時点では不明であり今後の研究課題であると考 える。

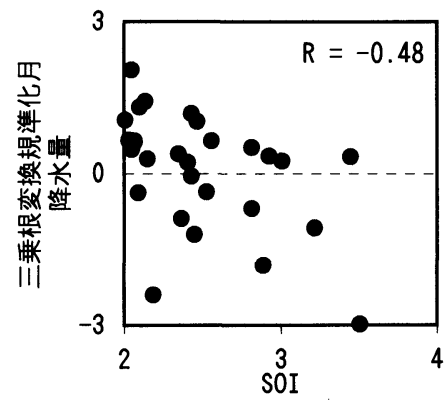

図-9 強いラニーニャ時における遅れ時間 $n=4$ ヶ月の三 乗根変換規準化月降水量散布図

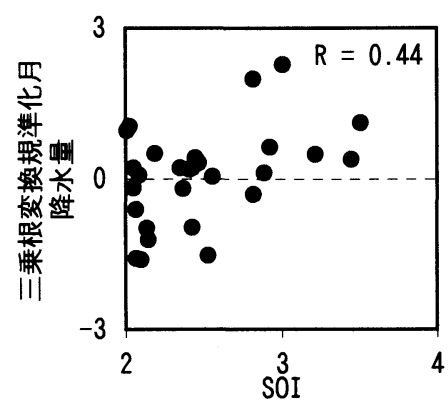

図-10 強いラニーニャ時における遅れ時間 $n=8$ ヶ月の三 乗根変換規準化月降水量散布図

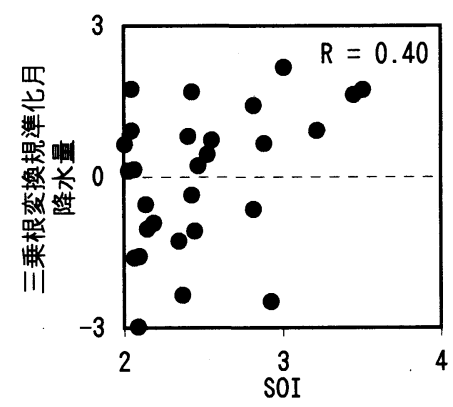

図-11 強いラニーニャ時における遅れ時間 $n=16$ ヶ月の 三乗根変換規準化月降水量散布図

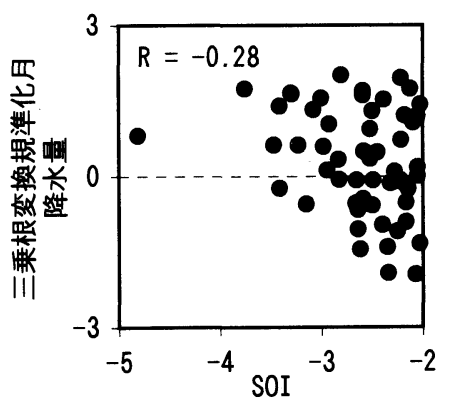

図-12 強いエルニーニョ時における遅れ時間 $n=2$ ヶ月の 三乗根変換規準化月降水量散布図 


\section{4. むすび}

本論文では, 110 年間 1320 ケ月の南方変動指数 (SOI) と正規変換した後規準化した福岡市月降水量 デー夕を用いて，南方振動と福岡市月降水量との 相関関係について解析・検討を行った．まず，南 方振動の相関について考察を加え, 相関係数その ものはそれ程大きくないものの極めて高い有意性 を保持していることを示した。 そして，SOI と降水 時系列全体を対象とした場合，両者の相関は予想 通りほとんどゼロであった。しかし，SOIをその大 きさによって 5 つのカテゴリーに分類して，カテ ゴリー別に相関関数を算定するという単純な解析 の結果, 強いエルニーニョ・強いラニーニャのカ テゴリーにおいて, 有意な相関を抽出することで きた。そして，例えば，強いラニーニャ時には， SOI が大きくなるほど, 4 ケ月後の福岡市月降水量 は平年に比べ少雨となる傾向にあること等を示し た. 従来, 日本のような中緯度における気候要素 と SOI との明瞭な相関は得られていなかったが， 本論文のように SOI をカテゴリー分類することに より，日本の他の地域でも有意な相関が抽出され る可能性があると考えられる.なお，本論文で得 られた有意な相関関係のより深い原因については， 今後の研究課題であると考える.

\section{参考文献}

1) 桜井邦雄 : エルニーニヨ現象の予測に向けて, 日本 に影響を及ぼす熱帯の気象，日本気象学会関西支部， pp.38-57,1998.

2）気候影響・利用研究会編：エルニーニヨと地球環境， 成山堂書店, 1999.

3) Kawamura, A., McKerchar, A.I., Spigel, R.H. and Jinno, K. : Chaotic characteristics of the Southern Oscillation Index time series, Journal of Hydrology, No.204, pp.168181, 1998.

4) Ropelewski, C.F. and Halpert, M.S. : Global and regional scale precipitation patterns as sociated with the El Niño/Southern Oscillation, Monthly Weather Review, Vol.115, pp.1606-1626, 1987.
5) Halpert, M.S. and Ropelewski, C.F. : Surface temperature patterns associated with the Southern Oscillation, Journal of Climate, Vol.5, pp.577-593, 1992.

6) Uvo, C.B., Repelli C.A., Zebiak S.E. and Kushnir, Y. : The relationships between tropical Pacific and Atlantic SST and northeast Brazil monthly precipitation, Journal of Climate, Vol.11, pp.551-562, 1998.

7）吉野文雄 : エル・ニーニヨ現象と四国の月降水量の 関係について, 平成 11 年度土木学会四国支部研究 発表会講演概要集, pp.90-91,1999.

8）新田尚：新気象読本, 東京堂出版，1988.

9）西森基貴, 吉野正敏 : ENSO 現象と台風の発生・発 達・経路との関係, 地理学評論, 第 63 巻 Ser.A, 第 8 号, pp.530-540, 1990.

10) Yoshino, M. and Park, H.S : Variations in the plant phenology affected by global warming, In: Glants, M. et al. (eds.), Climate change and plants in East Asia. Springer-Verlag, pp.93-107,1996.

11) 河村 明: 平成 6 年渴水一地域別の事例 - 福岡市一 昭和 53 年福岡大渴水との比較, 土木学会誌, 第 80 巻, 第 9 号, pp.96-97,1995.

12) Kawamura, A. and Jinno, K. : Integrated water resources management in Fukuoka Metropolitan Area, Environmental Research Forum, Vols.3\&4, pp.97-109, 1996.

13）河村 明, 江口聡一郎, 神野健二 : 南方振動指数 （SOI）およびその気圧デー夕の統計的特性について， 水工学論文集, 第 45 巻, pp.169-174, 2001.

14) Troup, A.J. : The "southern oscillation", Quarterly Journal of the Royal Meteorological Society, Vol.91, No.390, pp. 490-506, 1965.

15) McBride, J.L. and Nicholls, N. : Seasonal relationships between Australian rainfall and the Southern Oscillation, Monthly Weather Review, No.111, pp.1998-2004, 1983.

16）河村 明, 上田年比古, 神野健二：降水時系列の長 期的パターン変動の解析, 土木学会論文集, 第 363 号/II -4, pp.155-164, 1985.

17）鈴木栄一, 岡本雅典 : 降水量の分布とその正規化に 関する 2,3 の問題, 気象と統計, 第 6 巻, 第 3 号, pp.13-15, 1955.

(2001. 3. 23 受付)

\section{CORRELATION BETWEEN SOUTHERN OSCILLATION AND MONTHLY PRECIPITATION IN FUKUOKA}

\section{Akira KAWAMURA, Soichiro EGUCHI and Kenji JINNO}

\footnotetext{
The impacts of Southern Oscillation on climate are widespread and extend far beyond the tropical Pacific. However, the concrete influence is not so clear, especially in middle to high latitudes, including Japan. In this study, the correlation between monthly values of on one hand Southern Oscillation Index (SOI) and on the other hand normally standardized precipitation in Fukuoka, Japan, which is constantly exposed to high drought risk is investigated in detail using 110 years of data. For the original time series, no significant direct correlation is detected. However, statistically significant correlation coefficients are obtained when using SOI data categorized into five groups according to their magnitudes.
} 